Language Teacher Identities 


\section{NEW PERSPECTIVES ON LANGUAGE AND EDUCATION}

Series Editor: Professor Viv Edwards, University of Reading, Reading, Great Britain Series Advisor: Professor Allan Luke, Queensland University of Technology, Brisbane, Australia

Two decades of research and development in language and literacy education have yielded a broad, multidisciplinary focus. Yet education systems face constant economic and technological change, with attendant issues of identity and power, community and culture. This series will feature critical and interpretive, disciplinary and multidisciplinary perspectives on teaching and learning, language and literacy in new times.

\section{Recent Books in the Series}

Distance Education and Languages: Evolution and Change Börje Holmberg, Monica Shelley and Cynthia White (eds)

Ebonics: The Urban Education Debate (2nd edn) J.D. Ramirez, T.G. Wiley, G. de Klerk, E. Lee and W.E. Wright (eds)

Decolonisation, Globalisation: Language-in-Education Policy and Practice Angel M. Y. Lin and Peter W. Martin (eds)

Travel Notes from the New Literacy Studies: Instances of Practice Kate Pahl and Jennifer Rowsell (eds)

Social Context and Fluency in L2 Learners: The Case of Wales Lynda Pritchard Newcombe

Social Actions for Classroom Language Learning John Hellermann

Teaching English as an International Language: Identity, Resistance and Negotiation Phan Le Ha

\section{Other Books of Interest}

Cross-linguistic Similarity in Foreign Language Learning Håkan Ringbom

Developing Minority Language Resources Guadalupe Valdés, Joshua A. Fishman, Rebecca Chávez and William Pérez

Deep Culture: The Hidden Challenges of Global Living Joseph Shaules

Education for Intercultural Citizenship: Concepts and Comparisons Geof Alred, Mike Byram and Mike Fleming (eds)

From Foreign Language Education to Education for Intercultural Citizenship Michael Byram

Language and Identity in a Dual Immersion School Kim Potowski

Language Learning and Teacher Education: A Sociocultural Approach Margaret R. Hawkins (ed.)

Language, Space and Power: A Critical Look at Bilingual Education Samina Hadi-Tabassum

Online Intercultural Exchange: An Introduction for Foreign Language Teachers Robert O'Dowd (ed.)

Understanding Deaf Culture: In Search of Deafhood Paddy Ladd

For more details of these or any other of our publications, please contact: Multilingual Matters, Frankfurt Lodge, Clevedon Hall, Victoria Road, Clevedon, BS21 7HH, England

http://www.multilingual-matters.com 
NEW PERSPECTIVES ON LANGUAGE AND EDUCATION Series Editor: Viv Edwards

\section{Language Teacher Identities Co-constructing Discourse and Community}

Matthew Clarke 


\section{Library of Congress Cataloging in Publication Data}

Clarke, Matthew

Language Teacher Identities: Co-constructing Discourse and Community/Matthew Clarke.

New Perspectives on Language and education

Includes bibliographical references and index.

1. English language-Study and teaching-United Arab Emirates 2. English language-Study and teaching-Arabic speakers. 3. English teachers-Training of-United Arab Emirates 4. English language-United Arab Emirates 5.

Women-Education-United Arab Emirates 6. Second language acquisition. I. Title.

PE1068.T84C53 2008

428.007105357-dc22 2008000303

\section{British Library Cataloguing in Publication Data}

A catalogue entry for this book is available from the British Library.

ISBN-13: 978-1-84769-082-1 (hbk)

ISBN-13: 978-1-84769-081-4 (pbk)

\section{Multilingual Matters}

UK: Frankfurt Lodge, Clevedon Hall, Victoria Road, Clevedon BS21 7HH.

USA: UTP, 2250 Military Road, Tonawanda, NY 14150, USA.

Canada: UTP, 5201 Dufferin Street, North York, Ontario M3H 5T8, Canada.

Copyright () 2008 Matthew Clarke.

All rights reserved. No part of this work may be reproduced in any form or by any means without permission in writing from the publisher.

The policy of Multilingual Matters/Channel View Publications is to use papers that are natural, renewable and recyclable products, made from wood grown in sustainable forests. In the manufacturing process of our books, and to further support our policy, preference is given to printers that have FSC and PEFC Chain of Custody certification. The FSC and/or PEFC logos will appear on those books where full certification has been granted to the printer concerned.

Typeset by Saxon Graphics Ltd.

Printed and bound in Great Britain by the Cromwell Press Ltd. 